\title{
Effects of lead exposure on peripheral nerve in the cynomolgus monkey
}

\author{
D A PURSER, ' K R BERRILL,' AND S K MAJEED ${ }^{2}$ \\ From the Departments of Inhalation Toxicology ${ }^{1}$ and Pathology, ${ }^{2}$ Huntingdon Research Centre, Huntingdon, \\ Cambridgeshire PE18 6ES, UK
}

ABSTRACT The relationship between blood lead concentration and nerve conduction velocity has been examined, using the cynomolgus monkey as a model for human lead poisoning, with lead dose and blood lead concentration maintained under controlled conditions, to determine whether nerve conduction velocity could be used as an objective measure of the effects of lead on the nervous system at subclinical concentrations. Five cynomolgus monkeys were maintained at a blood lead concentration of $90-100 \mu \mathrm{g} \mathrm{Pb} / 100 \mathrm{ml}$ for nine months by daily oral dosing with lead acetate (12-15 mg Pb/kg body weight). Motor nerve conduction velocity in the ulnar nerve was measured, together with blood lead concentrations. Blood lead concentrations were proportional to lead intake, reaching a stable level within one to two weeks. Lead did not accumulate in the blood, and blood lead concentrations were found to decrease to a maintained plateau from initial high concentrations during the first seven days of dosing. The animals showed no clinical or behavioural evidence of lead poisoning at any time during the study, although there was a progressive decrease in blood packed cell volume, haemoglobin concentration, and erythrocyte concentration. The maximal motor nerve conduction velocity of the ulnar nerve remained constant throughout the study, although changes were observed in the conduction velocity of slowly conducting nerve fibres. At termination, intranuclear inclusions were found in the renal tubular cells of all animals as were focal areas of myelin degeneration. in the ulnar and sciatic nerves.

Although clear clinical signs of lead poisoning seldom occur in man at blood lead concentrations below $80 \mu \mathrm{g} \mathrm{Pb} / 100 \mathrm{ml}$, there is some evidence that lead poisoning has no clear threshold and that deleterious neuropsychological effects may occur at blood lead concentrations as low as $35 \mu \mathrm{g} \mathrm{Pb} / 100$ $\mathrm{ml}$, especially in children.' It has also been reported that changes may occur in peripheral nerve conduction velocity with blood lead concentrations in the $20-80 \mu \mathrm{g} \mathrm{Pb} / 100 \mathrm{ml}$ range..$^{2-9}$

In two studies it is claimed that there is a relationship between blood lead concentrations and the decrease in peripheral nerve conduction velocity with no obvious threshold, although the current detection threshold is at about $40 \mu \mathrm{g} \mathrm{Pb} / 100 \mathrm{ml}$ blood. ${ }^{34}$ It is therefore possible that changes in nerve conduction velocity could be used as objective clinical evidence for some of the neurological effects of low level lead exposure.

Received 6 September 1982

Accepted 15 November 1982
Environmental studies of nerve conduction velocity in man are subject to problems of variation in dose level and duration of exposure and contain no information on the dose of lead necessary to produce raised blood lead concentrations or the times of exposure necessary to produce changes in nerve conduction velocity. Nor do they give information on the extent to which such changes are stable, given a maintained blood lead concentration. A study was therefore designed to examine the relationship between blood lead concentration and nerve conduction velocity, using the cynomolgus monkey as a model for human lead poisoning, with lead dose and blood concentration maintained under controlled conditions. The preliminary study reported here was carried out to develop a dosing regimen capable of producing and maintaining suitable blood lead concentrations, to determine whether relatively high blood lead concentrations of $90-100 \mu \mathrm{g} \mathrm{Pb} / 100 \mathrm{ml}$ were capable of producing clear decreases in maximal motor nerve conduction velocity (MNCV) in cynomolgus monkeys, and to examine the time course and stability of any changes that might occur. 


\section{Materials and methods}

Five cynomolgus monkeys (Macaca fascicularis) aged about 2-3 years and weighing from 2.9 to 3.4 $\mathrm{kg}$ were dosed with an aqueous solution of lead acetate containing $4 \mathrm{mg} \mathrm{Pb} / \mathrm{ml}$ by oral gavage daily for nine months. The dose level was adjusted as shown below to maintain the animals with a blood lead approximately in the range $90-100 \mathrm{~Pb} / 100 \mathrm{ml}$ :

$\begin{array}{cc}\text { Week of study } & \begin{array}{c}\text { Dose level } \\ \text { (mg Pb/kg body weight) }\end{array} \\ 1 & 5 \cdot 0 \\ 2 & 7 \cdot 5 \\ 3 & 9 \cdot 0 \\ 4-9 & 10 \cdot 5 \\ 10-17 & 12 \cdot 0 \\ 18-38 & 15 \cdot 0\end{array}$

Initially, blood lead concentrations were estimated from $5 \mathrm{ml}$ blood samples taken on the morning of the third day each week, immediately before dosing. During weeks 9-35 measurements were made at approximately monthly intervals. The lead concentrations in whole blood were estimated by atomic absorption spectrophotometry against a standard curve prepared by adding different amounts of lead to $5 \mathrm{ml}$ samples of control monkey blood. To estimate background lead concentrations in the control blood a calibration curve was derived from aqueous standard lead solutions. As a further check six samples of monkey blood were sent to the Veterinary Investigation Centre, Madingley Road, Cambridge, UK, for analysis. Samples were prepared for analysis as follows: $1 \mathrm{ml}$ of a solution containing $5 \mathrm{~g}$ Triton $\mathrm{x}-100$ and $2 \mathrm{~g}$ ammonium pyrrolidine dithiocarbamate in $100 \mathrm{ml}$ water was added to a sample of blood $(5 \mathrm{ml})$ and mixed. After the addition of methyl isobutyl ketone $(5 \mathrm{ml})$ the mixture was shaken for two minutes and then centrifuged. The organic phase was removed and aspirated directly into the atomic absorption spectrophotometer.

For nerve conduction velocity measurements, an unanaesthetised animal was placed in a restraining chair and four loops of $0.1 \mathrm{~mm}$ diameter tinned copper wire were passed through the skin to provide two pairs of stimulating electrodes. Stimuli were applied at the ulnar fossa and over the ulnar nerve at the wrist. The recording electrodes consisted of loops of wire threaded through the skin of the hand, the anode placed $2 \mathrm{~cm}$ below the base of the little finger and the cathode in the first joint of the little finger. The electrical stimuli consisted of $0.2 \mathrm{~ms}$ duration square wave pulses with a supramaximal amplitude. The MNCV of the ulnar nerve was calculated from measurements of the response latency of the abductor digiti minimi muscle after elbow and wrist stimulation. The MNCV was determined from measurements of the conduction time of the main muscle response (the $\mathbf{M}$-wave) from elbow to wrist, and also by determining the conduction times of a secondary muscle response, the F-wave. The conduction time of the F-wave after wrist stimulation involves impulses passing from wrist to spinal cord and back to wrist, and the conduction time after elbow stimulation involves impulses passing from elbow to spinal cord and back to wrist. ${ }^{10}$ In all cases latencies were measured to the first deflection of the muscle action potential and conduction times were corrected to a standard limb temperature of $37^{\circ} \mathrm{C}$ using the formula of De Jesus et al. " Limb temperature was measured by inserting a thermistor probe into the forearm. The conduction velocity of slowly conducting ulnar motor fibres (CVSF) was determined by the technique of Seppalainen and Hernberg $^{12}$ in which a partial antidromic block is used. Stimulation at the wrist was followed after a progressively decreasing delay by stimulation at the elbow until a partial block caused the elbow response to decrease in amplitude. As a check on the calculations of nerve conduction velocities the ulnar nerve was exposed at postmortem examination between the spinal cord and the wrist, and the length measured from ventral root $\mathrm{C} 7$ to the wrist and from the ulnar fossa to the wrist. Measurements of conduction velocity were made five times during the month before dosing was started, weekly up to week 10 , and then at approximately monthly intervals up to week 37 . To obtain a block of data at the end of the study for comparison with the preexposure data, measurements were made once in week 36 and three times in week 37.

Routine haematology, blood biochemistry, and urine analyses were undertaken on six occasions, once pre-exposure and during weeks $4,9,19,27$, and 35 . The following measurements were made: erythrocyte sedimentation rate (ESR), packed cell volume (PCV), haemoglobin $(\mathrm{Hb})$, red cell count (RBC), reticulocyte count (with calculation of mean corpuscular haemoglobin ( $\mathrm{MCH})$, mean corpuscular haemoglobin concentration (MCHC), and mean corpuscular volume (MCV)), total and differential white cell count, plasma glucose, serum urea, total protein, albumin, glutamic-pyruvic-transaminase (GPT), glutamic-oxaloacetic-transaminase (GOT), leucine aminopeptidase (LAP), sodium, potassium, calcium, and creatinine. The urine was examined for total volume, $\mathrm{pH}$, relative density, protein, total reducing substances, glucose, ketones, bile pigments, urobilinogen, and blood pigments. Additionally a spun deposit was examined microscopically. At the termination of the study all animals were 


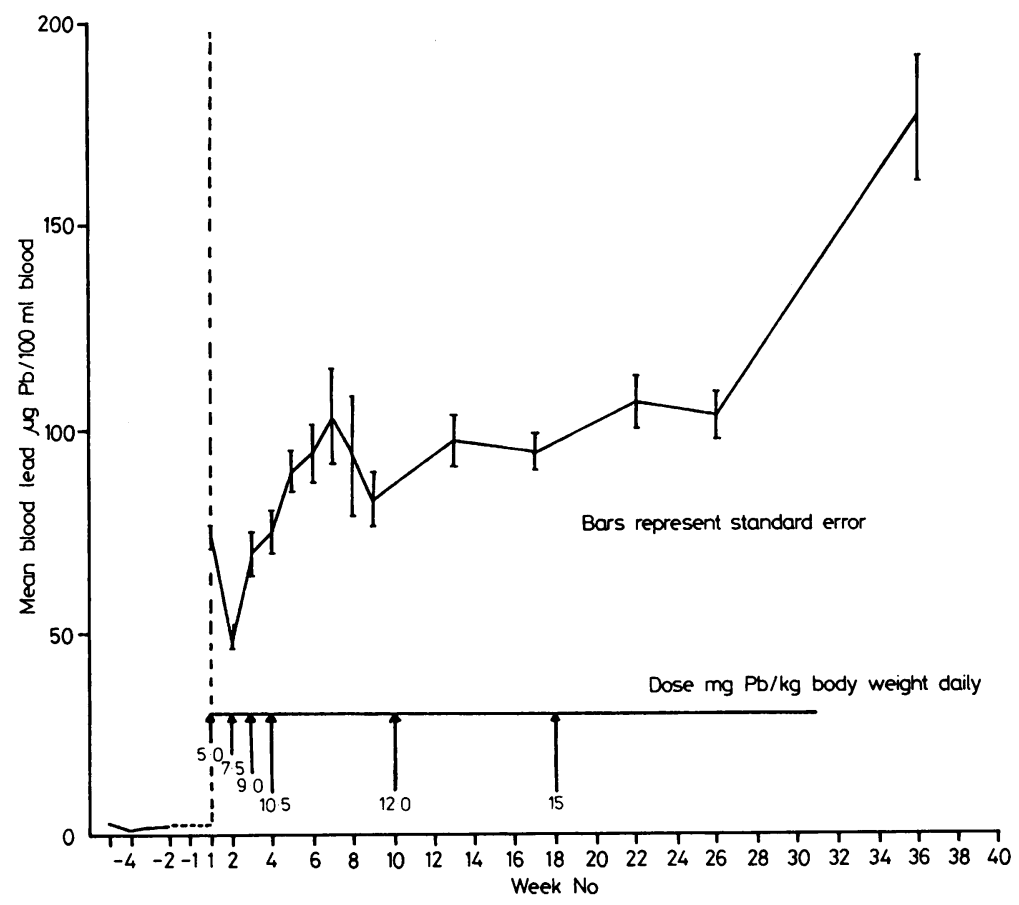

Fig 1 Mean blood lead concentrations throughout study.

anaesthetised with sodium pentobarbitone and killed by exsanguination. A full macroscopic postmortem examination was performed, and specimens of the following tissues were taken for histological examination and fixed in $10 \%$ buffered formalin: ulnar and sciatic nerves with muscle attachments, spinal cord, brain, and kidney.

Tissues were then routinely processed in paraffin wax $\left(56^{\circ} \mathrm{C} \mathrm{MP}\right)$, sectioned at $5 \mu \mathrm{m}$, and stained with haematoxylin and eosin. Differential staining of peripheral nerve for nerve fibre degeneration was also carried out using Glees Marslands and Luxol fast blue. In addition teasing of nerve fibres was performed on peripheral nerve from all monkeys using specimens fixed in $10 \%$ formalin restained with osmium tetroxide.

\section{Results}

Although the animals were maintained at blood lead concentrations of up to $90 \mu \mathrm{g} \mathrm{Pb} / 100 \mathrm{ml}$ for 33 weeks, they showed no clinical evidence of lead poisoning. The general condition of the animals, their body weights, and food consumption remained good throughout the study, and there was no evidence of behavioural abnormalities.

\section{BLOOD LEAD CONCENTRATIONS}

Figure 1 shows the mean blood lead concentrations throughout the study. The background concentrations measured before dosing began were found to be low ( $<9 \mu \mathrm{g} \mathrm{Pb} / 100 \mathrm{ml}$ blood) and it was therefore considered unnecessary to correct blood concentration estimates throughout the study for background concentrations.

Blood samples taken 24 hours after the second daily dose of $5 \mathrm{mg} \mathrm{Pb} / \mathrm{kg}$ body weight contained a mean concentration of $74.2 \mu \mathrm{g} \mathrm{Pb} / 100 \mathrm{ml}$, but after nine days of continued dosing the blood concentration had fallen to $48.6 \mu \mathrm{g} \mathrm{Pb} / 100 \mathrm{ml}$. Increasing the dose level of $10.5 \mu \mathrm{g} \mathrm{Pb} / \mathrm{kg}$ over the next three weeks produced a mean blood concentration of 90 $\mu \mathrm{g} \mathrm{Pb} / 100 \mathrm{ml}$ by week 10 , and the animals were maintained so far as possible within the range 90 $100 \mu \mathrm{g} \mathrm{Pb} / 100 \mathrm{ml}$ blood until the end of the study. Although there were some fluctuations in the blood lead concentrations of individual animals, they were maintained within the range $87-126 \mu \mathrm{g} \mathrm{Pb} / 100 \mathrm{ml}$ blood until week 26 . Only one set of samples was taken subsequently at week 36 and although the dose level had been kept constant since week 18 , the blood lead concentration was found to have increased over the period since week 26 to a mean 
Table 1 Nerve conduction velocities throughout the study. Figures in parentheses indicate standard deviations

\begin{tabular}{|c|c|c|c|c|c|}
\hline & $N^{*}$ & $\begin{array}{l}\text { MNCV M-wave } \\
(\mathrm{m} / \mathrm{s})\end{array}$ & $\begin{array}{l}M N C V F \text {-wave } \\
\text { elbow }(\mathrm{m} / \mathrm{s})\end{array}$ & $\begin{array}{l}\text { MNCV F-wave } \\
\text { wrist }(\mathrm{m} / \mathrm{s})\end{array}$ & $\begin{array}{l}\text { CVSF } \\
(\mathrm{m} / \mathrm{s})\end{array}$ \\
\hline $\begin{array}{l}\text { Pre-exposure } \\
\text { Exposure } \\
\% \text { change } \\
\text { Exposure } \\
\text { (monthly) }\end{array}$ & $\begin{array}{r}5 \\
20\end{array}$ & $\begin{array}{r}70.4 \\
72.2(4.5) \\
+\quad 2.3\end{array}$ & $\begin{array}{r}56 \cdot 0(2 \cdot 3) \\
56 \cdot 5(3 \cdot 2) \\
+\quad 0.9\end{array}$ & $\begin{array}{r}62.3(2.3) \\
62.6(2.6) \\
+\quad 0.5\end{array}$ & $\begin{array}{rr}46.1 & (3.0) \\
56.8 & (4.3) \\
+23.2 & \end{array}$ \\
\hline $\begin{array}{l}1 \\
2 \\
3 \\
4 \\
5 \\
6\end{array}$ & $\begin{array}{l}1 \\
1 \\
1 \\
1 \\
1 \\
1\end{array}$ & $\begin{array}{l}67.6 \quad(10 \cdot 0) \\
70 \cdot 3 \quad(4 \cdot 2) \\
70.0 \quad(5.3) \\
67.3 \quad(7.5) \\
76.7 \quad(15.2) \\
74.4 \quad(3.3)\end{array}$ & $\begin{array}{l}56.3(3.8) \\
58.1(3.6) \\
61.6(3.9) \\
58.0(4.9) \\
59.7(6.0) \\
58.2(2.7)\end{array}$ & $\begin{array}{l}61 \cdot 4(2 \cdot 8) \\
65 \cdot 0(1 \cdot 7) \\
64 \cdot 2(4 \cdot 8) \\
61 \cdot 1(4 \cdot 1) \\
62 \cdot 8(3 \cdot 4) \\
65 \cdot 1(2 \cdot 9)\end{array}$ & $\begin{array}{lr}46.0 & (17.6) \\
60.5 \quad(4.2) \\
61.8 \quad(8.8) \\
64.2(19.5) \\
53.3(11.4) \\
61.6 \quad(4.2)\end{array}$ \\
\hline $\begin{array}{l}8 \\
\% \text { change at } \\
8 \text { months }\end{array}$ & 4 & $72 \cdot 0 \quad(5 \cdot 1)$ & $\begin{aligned} & 58 \cdot 3(2 \cdot 7) \\
+ & 4 \cdot 1\end{aligned}$ & $61 \cdot 1(4 \cdot 1)$ & $69 \cdot 5 \quad(4 \cdot 5)$ \\
\hline
\end{tabular}

*No of occasions measured.

tExcluding monkey No 67.

All results shown corrected to $37^{\circ} \mathrm{C}$.

Table 2 Nerve conduction velocities $(\mathrm{m} / \mathrm{s})$ in individual animals, pre-exposure and at the end of the study. Figures in parentheses indicate standard deviations

\begin{tabular}{|c|c|c|c|}
\hline Animal No & Pre-exposure (5 occasions) & 8 months (4 occasions) & Difference \\
\hline $\begin{array}{l}\text { Mean MNCV M-wave } \\
67 \\
69 \\
71 \\
73 \\
75\end{array}$ & $\left.\left.\begin{array}{l}66 \cdot 2 \\
75 \cdot 5 \\
74 \cdot 7 \\
66 \cdot 7 \\
68 \cdot 9\end{array}\right\} \begin{array}{l}4 \cdot 3 \\
2 \cdot 9 \\
2 \cdot 8 \\
4 \cdot 9 \\
5 \cdot 1\end{array}\right)$ & $\left.\left.\begin{array}{l}63 \cdot 4 \\
75 \cdot 1 \\
75 \cdot 0 \\
72 \cdot 3 \\
74 \cdot 6\end{array}\right\} \begin{array}{l}2 \cdot 5 \\
2 \cdot 6 \\
5 \cdot 5 \\
4 \cdot 1 \\
3 \cdot 3\end{array}\right)$ & $\begin{array}{r}3.0 \\
-\quad 0.4 \\
0.3 \\
5.6 \\
5.7\end{array}$ \\
\hline $\begin{array}{l}\text { Mean MNCV F-wave at elbow } \\
67 \\
69 \\
71 \\
73 \\
75\end{array}$ & $\left.\left.\begin{array}{l}52 \cdot 5 \\
56 \cdot 3 \\
58 \cdot 3 \\
57 \cdot 2 \\
56 \cdot 1\end{array}\right\} \begin{array}{l}1 \cdot 0) \\
4 \cdot 5 \\
4 \cdot 0 \\
3 \cdot 5 \\
3 \cdot 8\end{array}\right)$ & $\begin{array}{l}\text { No data } \\
56 \cdot 6\left(\begin{array}{l}3 \cdot 2) \\
58 \cdot 3 \\
56 \cdot 1 \\
62 \cdot 0 \\
62 \\
1 \cdot 8 \\
2 \cdot 7\end{array}\right)\end{array}$ & $\begin{array}{r}0.3 \\
0.0 \\
-\quad 1 \cdot 1 \\
5.9\end{array}$ \\
\hline $\begin{array}{l}\text { Mean MNCV F-wave at wrist } \\
67 \\
69 \\
71 \\
73 \\
75\end{array}$ & 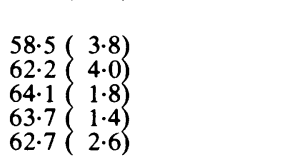 & 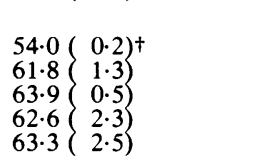 & $\begin{array}{l}-4.5^{*} \\
-0.4 \\
-0.3 \\
-1.1 \\
+0.6\end{array}$ \\
\hline $\begin{array}{l}\text { Mean CVSF } \\
67 \\
69 \\
71 \\
73 \\
75\end{array}$ & $\begin{array}{l}(4 \text { occasions) } \\
43.7(7.3) \\
47.3(3.4) \\
49.8(5.6) \\
42.6(7.6) \\
47.4(13.6)\end{array}$ & $\begin{array}{l}63 \cdot 4 \\
66 \cdot 5 \\
72 \cdot 6 \\
74 \cdot 3 \\
70 \cdot 9\end{array}\left(\begin{array}{r}5 \cdot 4) \\
11 \cdot 3 \\
5 \cdot 7 \\
3 \cdot 8)\end{array}\right.$ & $\begin{array}{l}19 \cdot 7^{* *} \\
19 \cdot 2^{* * 1 / 2} \\
22 \cdot 8^{* *} \\
31 \cdot 7^{* * *} \\
23 \cdot 5^{* * 1 / 2}\end{array}$ \\
\hline
\end{tabular}

${ }^{*} \mathrm{p}<0.05 ;{ }^{* *} \mathrm{p}<0.01 ;{ }^{* * 1 / 2} \mathrm{p}<0.02 ;{ }^{* * *} \mathrm{p}<0.001$.

+ Mean of three occasions.

level of $177.4 \mu \mathrm{g} \mathrm{Pb} / 100 \mathrm{ml}$ blood. The highest concentration was achieved by animal No 71 at the end of the study at $222 \mu \mathrm{g} \mathrm{Pb} / 100 \mathrm{ml}$ blood.

\section{NERVE CONDUCTION VELOCITY}

The results are summarised in table 1 in terms of the means of the pooled data corrected to $37^{\circ} \mathrm{C}$ obtained before, and on all occasions after, the start of dosing, and in terms of the data from single sets of measurements made at approximately monthly intervals throughout the study. The pooled data from four sets of measurements made at the end of the study during weeks 36 and 37 are also shown.
The MNCV as estimated by the three methods used was remarkably constant throughout the study, although there were some differences between the velocity estimates given by each method. There were no statistically significant differences between the pre-exposure estimates of the MNCV and those throughout the exposure period and at the end of the study after eight months of dosing. The MNCV estimates for individual animals before and at the end of the study are shown in table 2. Only one measurement, that of the mean MNCV of the F-wave evoked at the wrist for animal No 67 showed a significant apparent decrease in conduction veloc- 


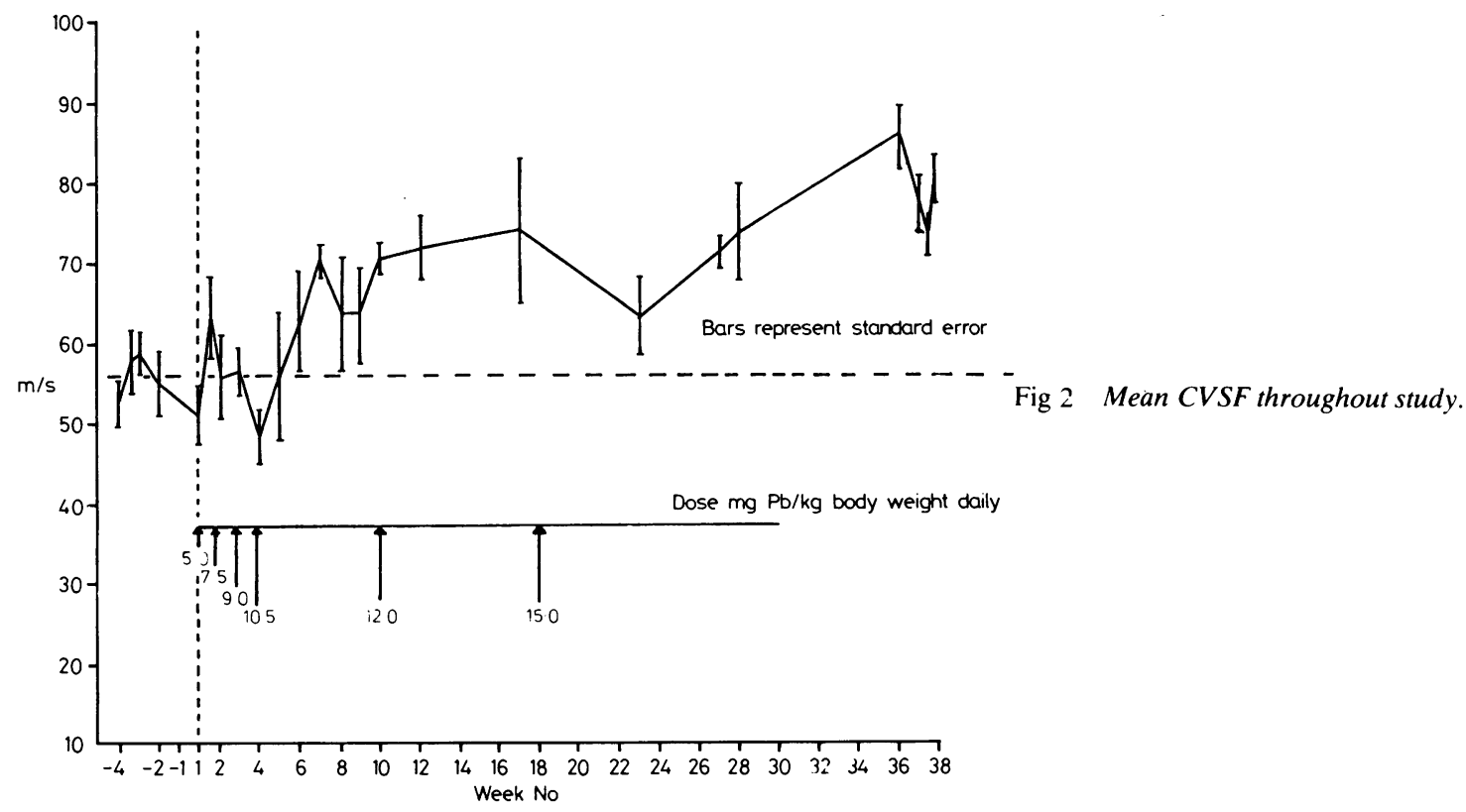

ity $(\mathrm{p}<0.05)$, but since the F-waves were small and difficult to evoke in this animal, and the eight month estimates are based on only three successful recordings, the result is not considered to be of great biological significance.

The CVSF does show changes over the course of the study, and after eight months of dosing the CVSF is highly significantly different from that before exposure $(p<0 \cdot 001)$. The differences were also statistically significant for each individual animal (table 2). The effect is of a progressive increase in apparent conduction velocity rather than the expected decrease. Figure 2 shows a graph of the mean CVSF throughout the study. Although there does appear to have been a slight apparent decrease in CVSF after three weeks of dosing, this was not statistically significant at the 5\% level. After three weeks there was a gradual increase in apparent CVSF towards the end of the study. The effect is illustrated in fig 3 for animal No 73 pre-exposure and after eight months. The increase in CVSF to some extent followed the increasing blood lead concentration (fig 1), and there was a significant linear relationship between blood lead concentration and $\operatorname{CVSF}(r=0.79, p<0.001)$.

To test the sensitivity of the technique for detecting changes in MNCV a regression analysis was performed of the mean arm temperature for each test session against the conduction time of the $\mathrm{M}$-wave between elbow and wrist, and of the F-wave between wrist and wrist. Although the temperature range throughout the study was small $\left(1 \cdot 6^{\circ} \mathrm{C}\right)$ there was a statistically significant linear relationship over this narrow range between temperature and both conduction time measures (for conduction time $M$-wave, $r=0.43, p<0.05$, for conduction time F-wave $r=0.40, p<0.05)$. Applying the regression equation for the $\mathrm{M}$-wave (where conduction time = $5.19-0.088 \times$ limb temperature in ${ }^{\circ} \mathrm{C}$ ), a $1{ }^{\circ} \mathrm{C}$ decrease in temperature from $37^{\circ}$ to $36^{\circ} \mathrm{C}$ resulted in a $4.6 \%$ increase in conduction time. Using the formula of De Jesus" ' an increase in conduction time of $4.5 \%$ is predicted.

\section{HAEMATOLOGY}

Several haematological changes were noted during the course of the study (table 3 ). The initial changes were a decrease in the mean $\mathrm{PCV}, \mathrm{Hb}$, and $\mathrm{RBC}$, all of which reached a minimum at week 19 and then showed a gradual recovery towards the end of the study. While the PCV and RBC recovered almost to pre-exposure levels, the recovery in $\mathrm{Hb}$ was slight, so that the mean $\mathrm{MCHC}, \mathrm{MCV}$, and $\mathrm{MCH}$ show a progressive decrease in both the amount and concentration of haemoglobin in each red cell throughout the study and there may have been a small decrease in mean red cell volume. Red cells with an abnormal cytological appearance were observed on several occasions; these consisted of hypochromasia, with a few target cells, anisocytosis, and rouleaux formation. There was also a significantly raised platelet concentration during the ninth and 


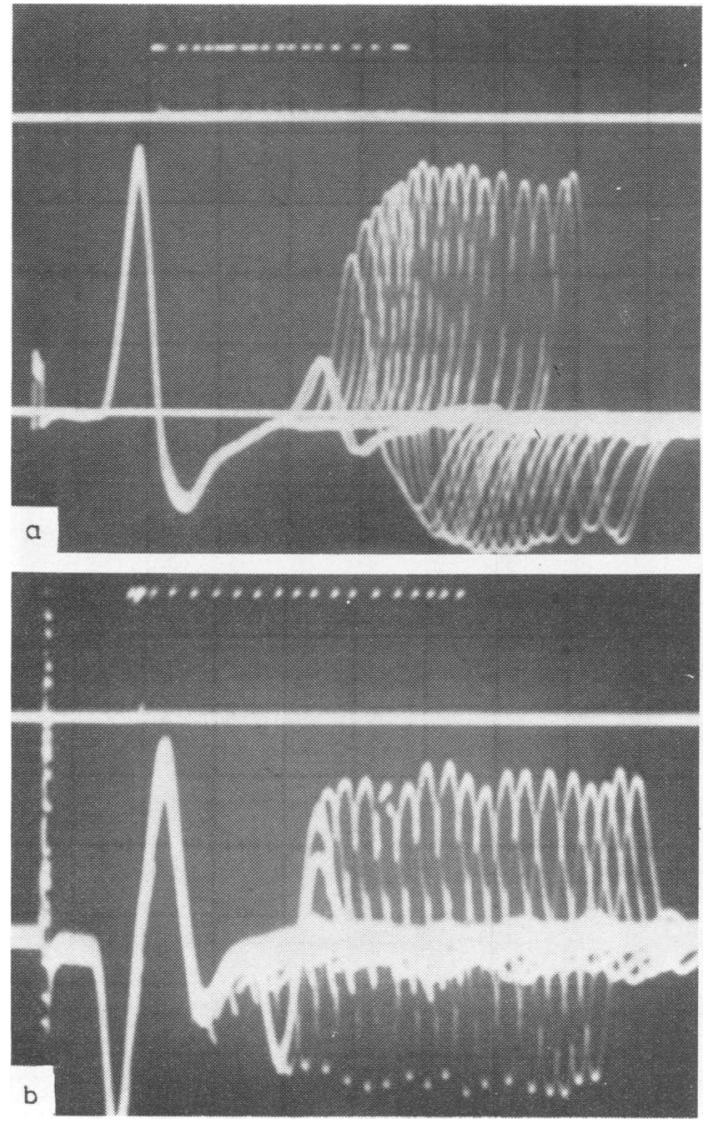

Fig 3 Recordings from monkey No 73 showing measurement of CVSF at beginning and end of study. (a) Recorded pre-exposure (29 August 1979). (b) Recorded during week 37 (4 June 1980). Time base $2 \mathrm{~ms} / \mathrm{cm}$.

nineteenth week which then appeared to decrease towards pre-exposure levels during the rest of the study.

BLOOD CHEMISTRY AND URINE ANALYSIS

No effects were observed in any of the tests performed.

\section{PATHOLOGICAL FINDINGS}

No macroscopic lesions were observed in any of these animals. Microscopic examination of the kidneys showed numerous eosinophilic intranuclear inclusion bodies in the renal tubular epithelial cells. Occasional instances of degeneration in individual nerve fibres were observed in the sciatic and ulnar nerves of all animals, with macrophages present in the neurilemmal tube.

Slides stained with haematoxylin and eosin showed evidence of nerve fibre degeneration with associated myelin degeneration. Differential staining with Glees Marslands showed evidence of nerve fibre degeneration with associated myelin degeneration shown by Luxol fast blue. Teasing of nerve fibres showed no clear evidence of nerve fibre degeneration. Schmidt-Lantermann clefts were prominent. The nerve lesions were most common in animals Nos 69, 71, and 73 (fig 4). No histopathological abnormalities were detected in the brain or spinal cord.

\section{Discussion}

\section{BLOOD LEAD CONCENTRATIONS}

The blood lead concentrations in our monkeys were approximately proportional to lead intake when dose levels were maintained constant for several weeks, with a level of approximately $10 \mu \mathrm{g} \mathrm{Pb} / 100$ $\mathrm{ml}$ blood for every $1 \mathrm{mg} \mathrm{Pb} / \mathrm{kg}$ body weight in the daily oral dose. It does not appear that with continuous dosing lead accumulates in the blood, although it may do so in the tissues. The relationship appears to be similar to that reported by Kehoe ${ }^{13}$ who used lower dose levels on human volunteers, and also found blood lead concentrations to be roughly proportional to intake.

What may be important in the context of acute (or intermittent) poisoning is that there was some adaptation to maintained lead dosing, and the initial blood concentrations were considerably higher than the maintained concentrations. There was a pronounced fall in blood lead concentration during the first nine days of dosing from a mean of $74.2 \mu \mathrm{g} \mathrm{Pb} /$ $100 \mathrm{ml}$ after two days to $48.6 \mu \mathrm{g} \mathrm{Pb} / 100 \mathrm{ml}$ after

Table 3 Haematological values showing progressive changes throughout the study. Figures in parentheses indicate standard deviations

\begin{tabular}{|c|c|c|c|c|c|c|c|}
\hline Week No & $P C V(\%)$ & $H b(\mathrm{~g} / 100 \mathrm{ml})$ & $R B C\left(\mathrm{mill} / \mathrm{mm}^{3}\right)$ & $M C H C(g \%)$ & $M C V\left(\mu m^{3}\right)$ & $M C H(\mu \mu g)$ & Platelets $\left(1000 / \mathrm{mm}^{3}\right)$ \\
\hline $\begin{array}{r}-5 \\
4 \\
9 \\
19 \\
27 \\
35\end{array}$ & $\begin{array}{l}43(1) \\
40(3) \\
40(2) \\
35(4) * \\
37(2) * * \\
40(3)\end{array}$ & $\begin{array}{l}12 \cdot 1(0.8) \\
11 \cdot 0(0.8)^{*} \\
10.3(0.4)^{*} \\
9.2(0 \cdot 5)^{* *} \\
9.4(0.5)^{* *} \\
9.7(0.4) * *\end{array}$ & $\begin{array}{l}6 \cdot 1(0 \cdot 5) \\
5 \cdot 8(0 \cdot 5) \\
5 \cdot 7(0 \cdot 3) \\
5 \cdot 4(0 \cdot 4) \\
5 \cdot 6(0 \cdot 3) \\
6 \cdot 1(0 \cdot 4)\end{array}$ & $\begin{array}{l}28(2) \\
28(1) \\
26(1) * * \\
26(2) * * * \\
25(1) * * \\
24(1) * *\end{array}$ & $\begin{array}{l}70(5) \\
68(2) \\
70(7) \\
65(5) * \\
67(1) \\
66(5)\end{array}$ & $\begin{array}{l}19.8(1.3) \\
18.9(1.3) \\
17.9(1.1)^{* *} \\
17.0(1.0)^{* *} \\
16.9(1 \cdot 1)^{*} \\
16 \cdot 1(0.9) * * *\end{array}$ & $\begin{array}{l}276(33) \\
352(78) \\
334(19) * * \\
317(49) * * \\
259(49) \\
282(48)\end{array}$ \\
\hline
\end{tabular}

* $p<0.05 ;{ }^{* *} p<0.01 ;{ }^{* * *} p<0.001$. 


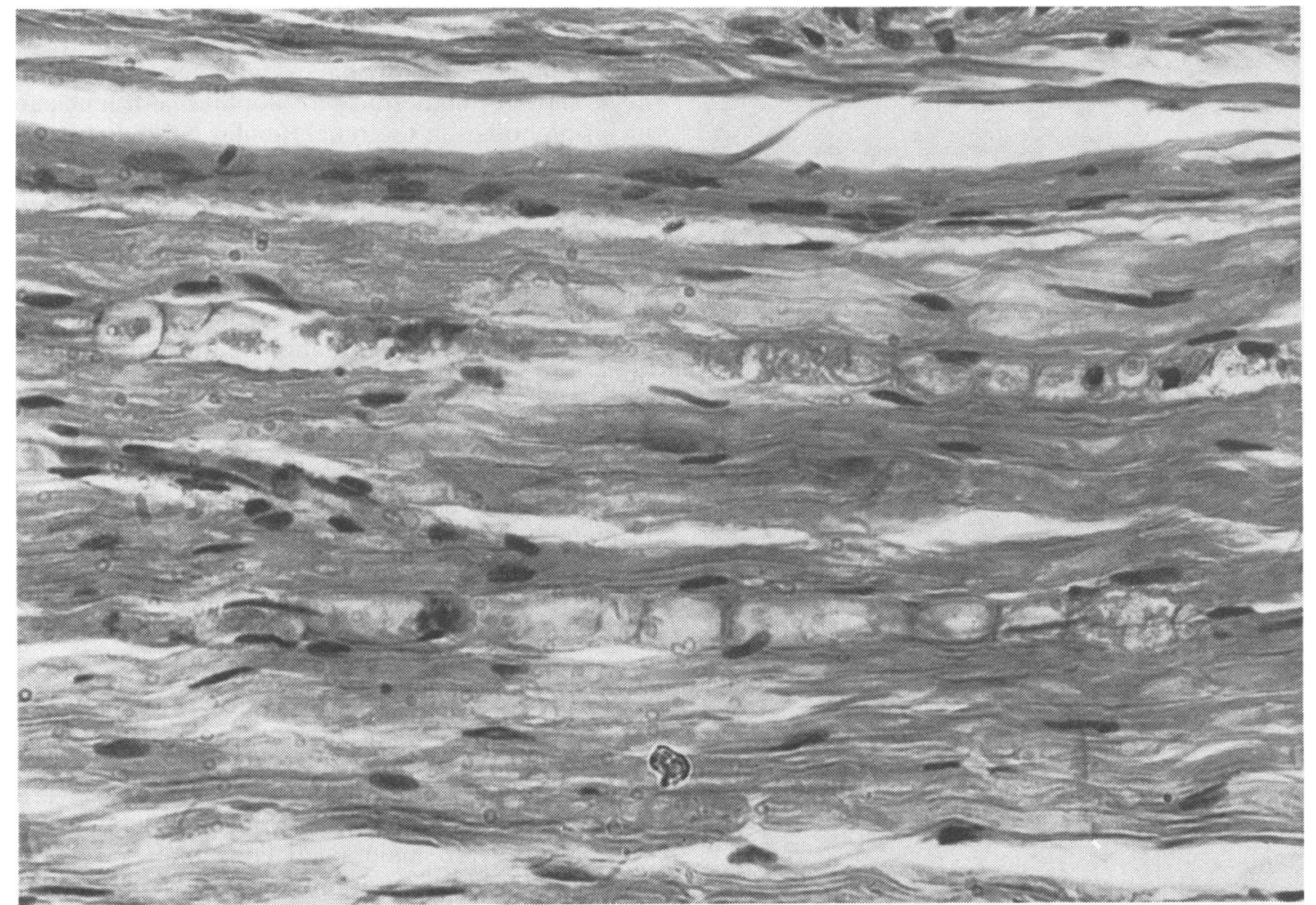

Fig 4 Myelin degeneration in ulnar nerve fibres-monkey No 73. Longitudinal section of ulnar nerve. (Haematoxylin and eosin; $X 250$.)

nine days, although the dose level was maintained at a constant $5 \mathrm{mg} \mathrm{Pb} / \mathrm{kg}$ body weight throughout this period. As the dose level was increased in gradual steps over the next eight weeks the tendency for the blood concentration to decrease became less pronounced, and the blood concentration remained fairly stable until the end of the regular blood lead measurements at week 26, although the terminal mean concentration of $177.4 \mu \mathrm{g} \mathrm{Pb} / 100 \mathrm{ml}$ taken at week 36 was surprisingly high as the dose level had been maintained constant since week 18 .

Similar blood level concentrations and a similar tendency for adaptation were reported by Goode and Calandra,${ }^{14}$ who dosed adult rhesus monkeys by mouth with $5 \mathrm{mg} \mathrm{Pb} / \mathrm{kg}$ for 30 months. They found that the blood lead concentration reached a peak of $82 \mu \mathrm{g} \mathrm{Pb} / 100 \mathrm{ml}$ after seven weeks of dosing and then decreased to $45-60 \mu \mathrm{g} \mathrm{Pb} / 100 \mathrm{ml}$, remaining at this concentration for the rest of the study. This occurrence of decreased blood lead concentrations with continuous dosing may explain an observation of Zook et al that monkeys appear to be able to tolerate high doses of lead given regularly without developing clinical signs of poisoning whereas there have been several cases of animals in zoological gardens dying from accidental lead poisoning having received apparently lower doses. ${ }^{15}$ It is interesting to note that with neonate and infant monkeys much lower doses of lead can give much higher blood lead concentrations. Allen et al gave infant rhesus monkeys $1 \cdot 7-2.3 \mathrm{mg} \mathrm{Pb} / \mathrm{kg}$ body weight and recorded blood lead concentrations of $500 \mu \mathrm{g} \mathrm{Pb} / 100 \mathrm{ml}$ within 3-5 weeks, ${ }^{16}$ and Bushnell et al using a dose level of $1 \mathrm{mg} \mathrm{Pb} / \mathrm{kg}$ weight obtained blood concentrations of $137-300 \mu \mathrm{g} \mathrm{Pb} / 100 \mathrm{ml}$ over nine weeks. ${ }^{17}$ These findings are consistent with the suggestion that whereas children of 1-3 years of age are thought to absorb up to $53 \%$ of ingested lead, ${ }^{18}$ adult humans are known to absorb only about $10 \% .^{13}$

\section{HAEMATOLOGY}

The earliest and most sensitive signs of lead exposure in man are usually those on haemoglobin synthesis. Decreased activity of aminolaevulinic acid dehydrase (ALA-D) has been reported at blood 
lead concentrations as low as $10-30 \mu \mathrm{g} \mathrm{Pb} / 100 \mathrm{ml}$, with increased excretion of the substrate aminolaevulinic acid (ALA) at blood levels in the $40-80 \mu \mathrm{g} \mathrm{Pb} / 100 \mathrm{ml}$ range ${ }^{19}$ together with increased coproporphyrin in urine and erythrocytes. Signs of anaemia and morphological changes in the erythrocytes occur at blood lead concentrations approaching $60 \mu \mathrm{g} \mathrm{Pb} / 100 \mathrm{ml}^{1920}$ or certainly at $70-80 \mu \mathrm{g}$ $\mathrm{Pb} / 100 \mathrm{ml}^{21}$ The degree of anaemia in man is, like many other signs, variable between individuals, and it is possible for an individual patient to show severe neurological signs of lead poisoning without anaemia, so that it is not regarded as a reliable sign of early lead poisoning.

With the exception of the biochemical changes, which were not measured, and basophilic stippling, which was not observed, all the common haematological changes associated with impaired haemoglobin synthesis in man as a result of lead exposure were observed in our monkeys as clear, statistically significant, and progressive changes. These were first detected after three weeks of dosing when the blood lead concentration was $69.4 \mu \mathrm{g} \mathrm{Pb} /$ $100 \mathrm{ml}$; although at no time during the study were the levels of haematological parameters below the lower limit of the range considered normal in cynomolgus monkeys in any individual animal. The changes were similar in individual animals and consistent from month to month, and were the only clear signs of lead intoxication observed during the study. Identical changes have been observed in other primate studies at similar threshold blood lead concentrations, which in turn are similar to the human threshold for erythrocyte changes. ${ }^{16} 17$

\section{RENAL EFFECTS OF LEAD ABSORPTION}

Lead accumulates in the form of intranuclear inclusions in renal tubular cells in man, and at high blood concentrations ( $>150 \mu \mathrm{g} \mathrm{Pb} / 100 \mathrm{ml}$ ) functional impairment and histological signs of tubular damage occur. Although we found a high percentage of intranuclear lead inclusions in the renal tubular cells of our monkeys, there was no clear evidence of functional renal impairment of histological damage, which is consistent with our lower maintained blood lead concentrations. Similar intranuclear inclusions have been reported in rhesus monkeys by Allen et $a l^{16}$ and Zook et $a l^{22}$ who obtained higher blood lead concentrations $(>200 \mathrm{mg} \mathrm{Pb} / 100 \mathrm{ml})$ and found evidence of functional impairment in the form of increased blood urea nitrogen, proteinuria, and glycosuria.

\section{NERVE CONDUCTION VELOCITY} $M N C V$

The basic finding of this study was that although the five animals were maintained at blood lead concentrations in excess of $90 \mu \mathrm{g} \mathrm{Pb} / 100 \mathrm{ml}$ for 33 weeks, with a mean concentration of $177 \mu \mathrm{g} \mathrm{Pb} / 100 \mathrm{ml}$ at the end of the study, there was no clear evidence for a decrease in the conduction velocity of the ulnar nerve.

The MNCV as estimated by the three methods used was remarkably constant throughout the study, although there were some differences between the velocity estimates given by each method, especially between the M-wave velocity $(70.4 \mathrm{~m} / \mathrm{s}, \mathrm{SD} 4.5)$ and the velocity of the F-waves at the elbow and wrist $(56.0 \mathrm{~m} / \mathrm{s}, \mathrm{SD} 2.3$ and $62.3 \mathrm{~m} / \mathrm{s}, \mathrm{SD} 2.3$ respectively). McLeod and Wray, investigating the $F$ =wave in baboons, found similar discrepancies and suggested that since the F-wave response is small, affecting only a few nerve fibres, it may not include the fastest fibres which are responsible for the initial deflection of the M-wave. ${ }^{10}$ They estimated F-wave velocity at $68-73 \mathrm{~m} / \mathrm{s}$ and $\mathrm{M}$-wave velocity at $75 \mathrm{~m} / \mathrm{s}$. The estimates of $\mathrm{M}$-wave conduction velocity for the ulnar nerve of human subjects used as controls in studies of lead workers were $56-64 \mathrm{~m} / \mathrm{s}$.

Our estimates of ulnar nerve MNCV in cynomolgus monkeys are thus similar to those obtained in baboons and in man, and the estimates of MNCV given by the three methods used were sufficiently consistent throughout the study that a real decrease in MNCV of as little as $7-10 \%$ should have been detectable. Of the methods used, the wrist $\mathrm{F}$-wave might be expected to give the most sensitive and accurate estimate of change in MNCV during the study, since it involves velocity measurements over the greatest length of nerve $(57 \mathrm{~cm})$, and although the mean decrease of $1.9 \%$ was not statistically significant, four monkeys did show slight decreases at the end of the study and the decrease was significant at the $5 \%$ probability level for one animal (No 67). The F-wave in this animal, however, was small and difficult to evoke, so that the result is considered to be of dubious biological significance.

The sensitivity of the technique can be shown by examining the effect of temperature on nerve conduction velocity. The limb temperature range throughout the study was only $1.6^{\circ} \mathrm{C}$, and a significant $(p<0.05)$ linear correlation was obtained over this narrow range between MNCV and temperature for both the $\mathrm{M}$-wave and F-wave, a $1{ }^{\circ} \mathrm{C}$ fall in temperature resulting in a $4.6 \%$ decrease in conduction velocity. This agrees well with the formula of De Jesus et al, which predicts a $4.5 \%$ decrease in conduction velocity for a $1^{\circ} \mathrm{C}$ fall in temperature. ${ }^{\prime \prime}$

CVSF

Although there were no clear changes in the 
Table 4 Effects of lead on nerve conduction velocity in man

\begin{tabular}{|c|c|c|c|c|c|c|c|c|c|c|}
\hline \multirow[t]{2}{*}{ Author } & \multicolumn{2}{|c|}{$\begin{array}{l}\text { No of } \\
\text { subjects }\end{array}$} & \multicolumn{2}{|c|}{$\begin{array}{l}\text { Blood lead } \\
(\mu \mathrm{g} \mathrm{Pb} / 100 \mathrm{ml})\end{array}$} & \multirow{2}{*}{$\frac{\begin{array}{l}\text { Exposure } \\
\text { (years) }\end{array}}{\text { Test }}$} & \multicolumn{2}{|c|}{$\begin{array}{l}M N C V \\
(m / s)\end{array}$} & \multirow[t]{2}{*}{$\begin{array}{l}\% \\
\text { change }\end{array}$} & \multirow[t]{2}{*}{$p$} & \multirow[t]{2}{*}{ Nerve } \\
\hline & Con & Test & Con & Test & & Con & Test & & & \\
\hline Araki and $\mathrm{Honma}^{4}$ & 39 & 19 & 12 & $\begin{array}{l}45 \\
(29-73)\end{array}$ & 18 & $59 \cdot 0$ & $53 \cdot 3$ & -9.7 & $<0.01$ & Median \\
\hline \multirow[t]{3}{*}{ Ashby ${ }^{9}$} & 94 & 94 & & 60 & $\begin{array}{l}15 \\
(0 \cdot 5-33)\end{array}$ & $\begin{array}{l}55 \cdot 6 \\
57 \cdot 3 \\
71 \cdot 1 \\
47 \cdot 6\end{array}$ & $\begin{array}{l}53 \cdot 4 \\
55 \cdot 9 \\
63 \cdot 9 \\
46 \cdot 1\end{array}$ & $\begin{array}{l}-\quad 4.0 \\
-\quad 2.4 \\
-\quad 10.1 \\
-\quad 3.2\end{array}$ & $\begin{array}{l}<0.05 \\
<0.01 \\
<0.0005 \\
<0.005\end{array}$ & $\begin{array}{l}\text { Ulnar } \\
\text { Median } \\
\text { Radial } \\
\text { Peroneal }\end{array}$ \\
\hline & 13 & 13 & & 57 & $<2$ & & & & & \\
\hline & & & & & $(0 \cdot 5-2)$ & $\begin{array}{l}58.0 \\
59.8 \\
74.1 \\
49.9\end{array}$ & $\begin{array}{l}55 \cdot 1 \\
58 \cdot 4 \\
58 \cdot 1 \\
46.6\end{array}$ & $\begin{array}{l}5.0 \\
-\quad 2.3 \\
-\quad 21.6 \\
-\quad 6.6\end{array}$ & $\begin{array}{l}<0.05 \\
\text { NS } \\
<0.005 \\
<0.05\end{array}$ & $\begin{array}{l}\text { Ulnar } \\
\text { Median } \\
\text { Radial } \\
\text { Peroneal }\end{array}$ \\
\hline Buchthal and Behse ${ }^{8}$ & & 20 & & $(70-140)$ & $(0 \cdot 4-33)$ & $\begin{array}{l}63.6 \\
51.0 \\
54.6\end{array}$ & $\begin{array}{l}58.1 \\
50.0 \\
50.7\end{array}$ & $\begin{array}{l}-8.6 \\
-\quad 2.0 \\
-\quad 7.1\end{array}$ & $\begin{array}{l}<0.001 \\
\text { NS } \\
<0.001\end{array}$ & $\begin{array}{l}\text { Median } \\
\text { Peroneal } \\
\text { Sural }\end{array}$ \\
\hline Repko et $a l^{7}$ & 55 & 85 & 18 & 46 & $\begin{array}{l}8 \\
(0 \cdot 3-34)\end{array}$ & $\begin{array}{l}59.9 \\
64.5 \\
45.7\end{array}$ & $\begin{array}{l}53.4 \\
55 \cdot 6 \\
48.0\end{array}$ & $\begin{array}{r}-10.8 \\
-\quad 8.9 \\
+\quad 4.9\end{array}$ & $\begin{array}{l}<0.00003 \\
<0.00003 \\
\text { NS }\end{array}$ & $\begin{array}{l}\text { Median } \\
\text { Ulnar } \\
\text { CVSF } \\
\text { ulnar }\end{array}$ \\
\hline Seppalainen $e t a l^{2}$ & 26 & 26 & $(10-13)$ & $\begin{array}{l}40 \\
(20-70)\end{array}$ & $\begin{array}{l}4 \cdot 6 \\
(1-17)\end{array}$ & $\begin{array}{l}58 \cdot 5 \\
58 \cdot 1 \\
47 \cdot 1\end{array}$ & $\begin{array}{l}54 \cdot 5 \\
55 \cdot 0 \\
42 \cdot 0\end{array}$ & $\begin{array}{l}-\quad 6.8 \\
-\quad 5.3 \\
-\quad 10.8\end{array}$ & $\begin{array}{l}<0.005 \\
<0.01 \\
<0.001\end{array}$ & $\begin{array}{l}\text { Median } \\
\text { Ulnar } \\
\text { CVSF } \\
\text { ulnar }\end{array}$ \\
\hline \multirow[t]{2}{*}{ Seppalainen et $a l^{3}$} & 34 & 61 & 10.5 & $\begin{array}{l}40 \\
\text { (TWA) }\end{array}$ & $5-10$ & $\begin{array}{l}61 \cdot 0 \\
60 \cdot 5 \\
45 \cdot 9\end{array}$ & $\begin{array}{l}59 \cdot 6 \\
60.7 \\
42.5\end{array}$ & $\begin{array}{l}-\quad 2.2 \\
+\quad 0.3 \\
-\quad 7.4\end{array}$ & $\begin{array}{l}\text { NS } \\
\text { NS } \\
<0.005\end{array}$ & $\begin{array}{l}\text { Median } \\
\text { Ulnar } \\
\text { CVSF } \\
\text { ulnar }\end{array}$ \\
\hline & 34 & 17 & $\begin{array}{c}10.5 \\
\text { (time of test }\end{array}$ & $\begin{array}{l}54 \cdot 9 \\
(\text { TWA) } \\
70+)\end{array}$ & 11 & $\begin{array}{l}61 \cdot 0 \\
60 \cdot 5 \\
45 \cdot 9\end{array}$ & $\begin{array}{l}57 \cdot 1 \\
60 \cdot 0 \\
43 \cdot 8\end{array}$ & $\begin{array}{l}-\quad 6.4 \\
-\quad 0.8 \\
-\quad 4.6\end{array}$ & $\begin{array}{l}<0.05 \\
\text { NS } \\
\text { NS }\end{array}$ & $\begin{array}{l}\text { Median } \\
\text { Ulnar } \\
\text { CVSF } \\
\text { ulnar }\end{array}$ \\
\hline Feldman et $a l^{6}$ & 25 & $\begin{array}{r}6 \\
13\end{array}$ & & $\begin{array}{l}48 \cdot 8 \\
79 \cdot 5\end{array}$ & $\begin{array}{l}4-10 \mathrm{mnth} \\
>1\end{array}$ & $\begin{array}{l}54 \cdot 1 \\
54 \cdot 1\end{array}$ & $\begin{array}{l}49 \cdot 0 \\
43 \cdot 2\end{array}$ & $\begin{array}{l}-9.4 \\
-\quad 20.1\end{array}$ & $\begin{array}{l}<0.05 \\
<0.001\end{array}$ & $\begin{array}{l}\text { Peroneal } \\
\text { Peroneal }\end{array}$ \\
\hline Verbek $^{5}$ & 10 & 11 & 20 & 40 & 49 days & $\begin{array}{l}60 \cdot 0 \\
44 \cdot 8\end{array}$ & $\begin{array}{l}58 \cdot 4 \\
46 \cdot 2\end{array}$ & $\begin{array}{r}2.7 \\
+\quad 3.1\end{array}$ & NS & $\begin{array}{l}\text { Ulnar } \\
\text { CVSF } \\
\text { ulnar }\end{array}$ \\
\hline
\end{tabular}

NS = Not statistically significant.

Con $=$ Control.

MNCV, the estimates of CVSF showed progressive changes throughout the study. The apparent decrease that occurred during the first few weeks of the study, which reached a level of a $17 \cdot 1 \%$ decrease after three weeks, was not significant at the 5\% probability level, but the subsequent progressive apparent increase in the CVSF reached a level of a $51 \%$ increase at the end to the study after nine months, at which point both the mean CVSF and those of each individual animal differed significantly from the pre-exposure values (mean CVSF $\mathrm{p}<$ 0.001 , individual animals $p<0.02-<0.001$ ). Since the increase in CVSF to some extent mirrored the increases in blood lead concentration throughout the study (figs 1 and 2), and there was a significant linear relationship between blood lead concentrations and CVSF $(r=0.79, p<0.001)$ it is possible that the changes in CVSF were due either to the absolute blood lead concentration or the duration of exposure, or both.

It is unlikely, however, that the true conduction velocity of the slowly conducting fibres increased during the experiment and one possible explanation for this finding is that the slow fibres ceased to function. The CVSF technique is designed to detect the decrease in amplitude of the distal action potential that occurs when the slow fibres become refractory (fig 3). ${ }^{12}$ If the slowest fibres are blocked then the decrease in amplitude will not occur until faster fibres that are not blocked become refractory and this will result in an apparent increase in CVSF. This explanation is consistent with the decrease in CVSF that occurred early in the study. It may be that the initial effects of lead intoxication produced a slowing of conduction velocity in these slow fibres, and that as the study progressed the slow fibres ceased to function, resulting in the apparent increase in conduction velocity which was observed. In a similar study of the effects of lead exposure on nerve conduction velocity in man, Repko et al found a decreased MNCV in the ulnar nerve of lead workers compared with controls, but an apparently increased CVSF, although the increase was only $5 \%$. $^{7}$

Leaving aside the question of CVSF, the problem remains as to why no clear decreases in MNCV were detected in our cynomolgus monkeys when 
decreases in both MNCV and CVSF have been reported in people exposed to lead who display no other clinical signs of lead poisoning and who have blood lead concentrations below those maintained in our monkeys (table 4). In most of these studies relatively large numbers of lead exposed workers (19-94) were examined, and although statistically significant decreases in MNCV or CVSF of both were found in test subjects relative to age matched controls, the differences were often very small. The effects on the MNCV of the ulnar nerve varied from none $^{3}$ to a decrease of $8.9 \% \%^{7}$ with an average decrease over all studies of about $5 \%$ for subjects with mean blood lead concentrations of 40 to over $70 \mu \mathrm{g} \mathrm{Pb} / 100 \mathrm{ml}$ and mean exposure times of five to 15 years. The effects on the CVSF of the ulnar nerve varied between a decrease of $10.8 \%^{2}$ and $7 \cdot 4 \%^{3}$ to an increase of $4.9 \% .^{7}$ These findings are close to or within our limits of detection with five animals of a $7-10 \%$ decrease of nerve conduction velocity, so that even if the small changes associated with low level lead exposure in man had occurred in our animals it is possible that we would have been unable to detect them.

The aim of our project, however, was to determine whether there was a relationship between blood lead concentration and nerve conduction velocity in monkeys, and this pilot study was set up with deliberately high maintained blood lead concentrations of $90-100 \mu \mathrm{g} \mathrm{Pb} / 100 \mathrm{ml}$, on the basis that if such a relationship existed in monkeys, large decreases in nerve conduction velocity might be expected. Of the studies in man, four have attempted to show such a relationship, and two claim to have succeeded. Araki and Honma found a significant correlation between blood lead concentration and $\mathrm{MNCV}$ in the median and posterior tibial nerves in a study of 36 lead workers with blood concentrations in the range 2-73 $\mu \mathrm{g} \mathrm{Pb} / 100 \mathrm{ml}^{4}$; blood lead concentrations in excess of $70 \mu \mathrm{g} \mathrm{Pb} / 100 \mathrm{ml}$ giving a decrease in MNCV of about $20 \%$. Seppalainen et al found a similar correlation in the median and posterior tibial nerves in a study of 112 subjects with time weighted average (TWA) blood lead concentrations in the $25-55 \mu \mathrm{g} \mathrm{Pb} / 100 \mathrm{ml}$ range. ${ }^{3}$ From their regression line, subjects with blood lead concentrations of $90 \mu \mathrm{g} \mathrm{Pb} / 100 \mathrm{ml}$ would also be expected to show a $20 \%$ decrease in MNCV.

If $20 \%$ decreases in MNCV of the type predicted by these studies had occurred in our monkeys they should have been detectable. Two other human studies, however, have failed to find any relationship between blood concentrations and MNCV decrease. Buchtal and Behse examined subjects with blood lead concentrations in the $70-140 \mu \mathrm{g} \mathrm{Pb} / 100 \mathrm{ml}$ range ${ }^{8}$ levels similar to those in our monkeys, and found no significant correlation. Ashby examined 94 lead exposed subjects with a mean concentration of $60 \mu \mathrm{g} \mathrm{Pb} / 100 \mathrm{ml},{ }^{9}$ and actually found a statistically significant correlation $(\mathrm{p}<0.05), \mathrm{MNCV}$ increasing with increasing blood lead concentration.

The studies of lead exposures and MNCV in man suggest that real decreases in MNCV do occur, even after exposures of a few months, ${ }^{69}$ but that the decreases are small (5-6\%) and the effects on particular nerves and in individual subjects vary. Thus an individual subject may have a blood lead concentration of up to $140 \mu \mathrm{g} \mathrm{Pb} / 100 \mathrm{ml}$ and still maintain a normal nerve conduction velocity after many years of exposure,$^{8}$ and it is still open to question as to whether high levels of lead exposure in man produce greater decreases in MNCV. It may also be that monkeys are less susceptible than man to effects on the peripheral nerves. The only other study of the effect of lead on the MNCV in a non-human primate, that of Hopkins in the baboon, ${ }^{23}$ failed to show any effects on MNCV or any histopathological effect on peripheral nerve, although the blood lead concentrations were extremely high (often in excess of $500 \mu \mathrm{g} \mathrm{Pb} / 100 \mathrm{ml}$ blood) and several of his animals died of lead encephalopathy.

Experimental changes in nerve conduction velocity associated with lead have, in fact, been reported in only one study in animals, in which guinea pigs were given high and often fatal doses of lead (117$390 \mathrm{mg} \mathrm{Pb} / \mathrm{kg}$ body weight). ${ }^{24}$ Large (60-80\%) decreases in MNCV were associated with clear histopathological evidence of both axonal degeneration and segmental demyelination. Similar lesions have since been reported in rats ${ }^{25} 26$ but the MNCV was not measured. Segmental demyelination has never been shown in man or any other primate in association with lead poisoning, however, and the reasons for the small decreases observed in MNCV in man are not known. ${ }^{8}$

In our study teasing of nerve fibres showed no appreciable nerve fibre degeneration and no evidence of segmental demyelination, which is consistent with the minor neuropathological lesions observed by light microscopy. Although no concurrent control animals were available for this study, the peripheral nerves of large numbers of cynomolgus monkeys have been examined at our laboratory. Isolated instances of spontaneous swelling in single nerve fibres are observed in rare cases but the lesions seen in the lead intoxicated monkeys responded to differential staining by Glees Marslands and Luxol fast blue, indicating specific axonal and myelin degeneration. These findings correlate well with the physiological evidence that despite nine months of dosing with high level of lead no changes could be detected in the MNCV, while the 
minor lesions found in the peripheral nerve were associated with changes only in CVSF.

The discovery of instances of nerve fibre degeneration when there was no effect on the MNCV, however, shows that histological changes can exist in the presence of apparently normal physiology. On the other hand, it may be that the histological changes and the apparent changes in CVSF are early signs of a developing neuropathy.

\section{References}

${ }^{1}$ Department of Health and Social Security. Lead and health. (Report of the DHSS working party on lead in the environment. London: HMSO, 1980. (Lawther report.)

${ }^{2}$ Seppalainen AM, Tola S, Hernberg S, Kock B. Subclinical neuropathy at "safe" levels of lead exposure. Arch Environ Health 1975;30:180-3.

${ }^{3}$ Seppalainen AM, Hernberg S, Kock B. Relationship between blood lead levels and nerve conduction velocities. Neurotoxicology 1979;1:313-32.

${ }^{4}$ Araki S, Honma T. Relationships between lead absorption and peripheral nerve conduction velocities in lead workers. Scand $J$ Work Environ Health 1976;4:225-31.

5 Verbek MM. Motor nerve conduction velocity in volunteers ingesting inorganic lead for $\mathbf{4 9}$ days. Int Arch Occup Environ Health 1976;38:141-3.

- Feldman RG. Hayes MK, Younes R, Aldrich FD. Lead neuropathy in adults and children. Arch Neurol 1977;34:481-8.

${ }^{7}$ Repko JD, Corum CR, Jones PD, Garcia LS. The effects of inorganic lead on behavioural and neurologic function. DHEW (NIOSH) publication No 78-128.) Washington: Department of Health Education and Welfare (National Institute for Occupational Safety and Health), 1978.

${ }^{8}$ Buchthal F, Behse F. Electrophysiology and nerve biopsy in men exposed to lead. Br J Ind Med 1979;36:135-42.

- Ashby JAS. A neurological and biochemical study of early lead poisoning. Br J Ind Med 1980;37:133-40.

${ }^{10}$ McLeod JG, Wray SH. An experimental study of the F-wave in the baboon.J Neurol Neurosurg Psychiatry 1966;29:196-200.

"De Jesus PV, Hausmanowa-Petrusewicz I, Barchi RL. The effects of cold on nerve conduction of human slow and fast nerve fibres. Neurology 1973;23:1182-9.
${ }^{12}$ Seppalainen AM, Hernberg S. Sensitive technique for detecting subclinical lead neuropathy. Br J Ind Med 1972;29:443-9.

${ }^{13}$ Kehoe RA. Normal metabolism of lead. Arch Environ Health 1964;8:232-5.

14 Goode SJ, Calandra JC. Evaluation of chronic oral administration of lead acetate to rhesus monkeys. Toxicol Appl Pharmacol 1973;25:465. (Abstract 70.)

is Zook BC, London WT, Sever JL, Sauer RM. Experimental lead paint poisoning in non-human primates. I. Clinical signs and course. J Med Primatol 1976;5:23-40.

${ }^{16}$ Allen JR, McWey PJ, Suomi SJ. Pathobiological and behavioural effects of lead intoxication in the infant rhesus monkey. Environ Health Perspect 1974;7:239-46.

17 Bushnell PJ, Bowman RE, Allen JR, Marlar RJ. Scotopic vision deficits in young monkeys exposed to lead. Science 1977;196:333-5.

${ }^{18}$ Alexander FW, Delves HT, Clayton BE. Environmental health aspects of lead. Luxembourg: Commission of European Communities Directorate General for Dissemination of Knowledge. Centre for Information and Documentation CID, 1973; 319-31.

${ }^{19}$ Repko JD, Corum CR. Critical review and evaluation of the neurological and behavioural sequelae of inorganic lead absorption. In: Goldberg L, ed. Critical reviews in toxicology. Florida: CRC Press, 1979: 136-87.

${ }^{20}$ Zeilhuis RL. Second international workshop: permissable levels for occupational exposure to inorganic lead. Int Arch Occup Environ Health 1977;39:59-72.

${ }^{21}$ Tsuchiya K. Lead. In: Friberg L, Nordberg GF, Vouk VB, eds. Handbook on the toxicology of metals. Amsterdam: Elsevier/ North-Holland Biomedical Press, 1979: 451-84.

22 Zook BC, London WT, DiMaggio JF. Rothblat LA, Sauer RM Sever JL. Experimental lead poisoning in nonhuman primates II. Clinical pathologic findings and behavioural effects. J Med Primatol 1980;9:286-303.

${ }^{23} \mathrm{Hopkins} \mathrm{A}$. Experimental lead poisoning in the baboon. $\mathrm{Br} \mathrm{J}$ Ind Med 1970;27:130-40.

${ }^{24}$ Fullerton PM. Chronic peripheral neuropathy produced by lead poisoning in guinea pigs. J Neuropathol Exp Neurol 1966;25:214-36.

${ }^{25}$ Lampert PW, Schochet SS. Demyelination and remyelination in lead neuropathy. Electron microscope studies. J Neuropathol Exp Neurol 1968;25:527-45.

${ }^{26}$ Schlaepfer WW. Experimental lead neuropathy: a disease of the supporting cells in the peripheral nervous system. $J$ Neuropathol Exp Neurol 1969;28:401-18. 